\title{
ADSORPTION OF CARBON DIOXIDE ON MIL53(AL), CUBTC AND K- NAX
} ZEOLITE

\section{Alev GÜNEȘ YERKESIKLI}

Izmır Instıtute Technology, Urla-Izmir, Turkey

Seher Fehime ÇAKICIOĞLU-ÖZKAN

Izmır Instıtute Technology, Urla-Izmir, Turkey

\begin{abstract}
$\mathrm{CO}_{2}$ adsorption on $\mathrm{K}$ exchanged $\mathrm{NaX}$ zeolites, and metal organic frameworks (MOFs), namely $\mathrm{Cu}-\mathrm{BTC}$ and MIL53 (Al) was studied at $5{ }^{\circ} \mathrm{C}$ and $25^{\circ} \mathrm{C}$. Exchange via ultrasonic and traditional methods, was conducted at $50{ }^{\circ} \mathrm{C}$ and $70{ }^{\circ} \mathrm{C}$. The maximum replacement of $\mathrm{Na}^{+}$ion with $\mathrm{K}^{+}$ ion in the extra framework of zeolite was increased from $76 \%$ to $83 \%$ with increasing temperature from $50{ }^{\circ} \mathrm{C}$ to $70{ }^{\circ} \mathrm{C}$ in the ultrasonic method which is more effective than traditional one. Compared with the zeolites, the MOF adsorbents used in this work have higher Langmuir specific surface area values namely 1278, 1473 and about $1000 \mathrm{~m}^{2} / \mathrm{g}$ for MIL 53, CuBTC and zeolite adsorbents respectively. The resulting $\mathrm{CO}_{2}$ isotherms can be well represented by the Toth equation. Comparison of the isosteric heat of adsorption at zero loading shows that $\mathrm{CO}_{2}$ was adsorbed more weakly on MOFs than zeolites.
\end{abstract}

Keywords: $\mathrm{CO}_{2}$, adsorption, Ultrasound, $\mathrm{NaX}$ zeolite, $\mathrm{MOF}$

\section{INTRODUCTION}

Global warming resulting from the emission of greenhouse gases, especially $\mathrm{CO}_{2}$ has become a widespread concern in recent years. Adsorption of $\mathrm{CO}_{2}$ is caused by van der Waals between adsorbate and adsorbent, as well as by electrostatic interactions between the large quadrupole of $\mathrm{CO}_{2}\left(14.29 \times 10^{-40} \mathrm{C} \mathrm{m}^{-2}\right)$ and the ionic or polar sites of the solid adsorbent surface. Adsorbent selection is very important for the rational design of the adsorption processes such as pressure swing adsorption, vacuum swing adsorption and thermal swing adsorption. During the last decade, MOFs as a new family of nanoporous materials ${ }^{1}$ are assembled by directly bonding metal clusters with organic linkers. A variety of adsorbents have been investigated as potential $\mathrm{CO}_{2}$ adsorption materials including microporous and mesoporous materials such as metal aluminum silicates, aluminum phosphates and metal organic frameworks (MOFs). ${ }^{2-13}$ In contrast to the tetrahedral building blocks in zeolites which are silicons or aluminum oxides, MOFs can be comprised of inorganic clusters (e.g. square-shaped, trigonal, tetrahedral and octahedral) and organic linkers (e.g. carboxylates, imidazolates and tetrazolates). With very high surface area (up to $6500 \mathrm{~m}^{2} / \mathrm{g}$ ) MOFs have been considered versatile materials for adsorption ${ }^{14}$. MOFs have higher capacity $(11 \mathrm{mmol} / \mathrm{g}$ to $32 \mathrm{mmol} / \mathrm{g}$ ) at $30 \mathrm{~atm}$ pressure and 
$298 \mathrm{~K}$; however, at atmospheric pressures their capacity (0.95 mmol/g) is lower ${ }^{13}$ as compared to zeolites ${ }^{3,9,11,12}$ and aluminum phosphate. ${ }^{5}$ Zeolites, especially NaX, are commonly used adsorbents for $\mathrm{CO}_{2}$ adsorption at $1 \mathrm{~atm} .{ }^{11,12}$.

Acidic $\mathrm{CO}_{2}$ molecules can be adsorbed on the basic sites of the zeolite surfaces, the strength of which was increased along with an increase of the aluminum content. The presence of aluminum atoms in zeolites introduces negative framework charges that are compensated with exchangeable cations (extra framework cations) such as $\mathrm{Ca}^{2+}, \mathrm{Mg}^{2+}, \mathrm{K}^{+}$and $\mathrm{Na}^{+}$. According to Walton et al. ${ }^{15}$ the introduction of small univalent molecule via ion exchange enhances the adsorption of $\mathrm{CO}_{2}$ on the $\mathrm{X}$ zeolites with the order of:

$\mathrm{Cs}^{+}<\mathrm{Rb}^{+}<\mathrm{K}^{+}<\mathrm{Na}^{+}<\mathrm{Li}^{+}$.

Even the adsorption of $\mathrm{CO}_{2}$ in conventional ion-exchanged $\mathrm{X}$ zeolites has been studied previously. ${ }^{15-17}$ There has not been an investigation of ultrasound effect in the preparation of $\mathrm{K}$ exchanged $\mathrm{NaX}$ zeolite and its effect on $\mathrm{CO}_{2}$ adsorption. In literature, ultrasonic method as compared to the traditional exchange method was found to be very effective on the exchanged amount at equilibrium. ${ }^{18}$

In this paper, we studied $\mathrm{CO}_{2}$ adsorption on two types of adsorbents: K exchanged $\mathrm{NaX}$ zeolites (KNaXs) which were prepared with ultrasonic and traditional methods and commercial metal organic frameworks (MOFs): Cu-BTC and MIL53 (Al).

\section{RESULTS AND DISCUSSION}

\subsection{Characterization of Adsorbents}

\subsubsection{Zeolite Adsorbents}

Textural properties and the Na exchange percent (number in the parenthesis in case of zeolites) of the adsorbents are given in Table 1 . As seen in the table, the temperature was effective on the Na exchange method, and the maximum Na exchange percent obtained were $83 \%$ and $81 \%$ at $70{ }^{\circ} \mathrm{C}$ when ultrasonic and traditional methods were applied, respectively. The table also shows that $\mathrm{K}$ exchanged $\mathrm{NaX}$ have lower langmuir surface area, micropore volume and pore diameter than $\mathrm{NaX}$ zeolite. This can be explained with the restriction of available pores because $\mathrm{K}^{+}$ions are bigger ions than $\mathrm{Na}^{+}\left(\mathrm{R}_{\mathrm{K}^{+}}>\mathrm{R}_{\mathrm{Na}}\right)$ ions. The micrographs of the surface obtained from the scanning electron microscope show that the spherical crystal size $(2 \mu \mathrm{m})$ of $\mathrm{NaX}$ zeolite did not change with $\mathrm{K}^{+}$ion exchange applied (Figure 1). Comparison of the XRD spectra (Figure 2) of zeolite adsorbents shows that the $\mathrm{NaX}$ zeolite has the highest peak intensities and highly crystalline material but it is reduced with $\mathrm{K}^{+}$exchange as mentioned in the literature. ${ }^{19}$ This confirms the migration of cations to zeolite extraframework sites without affecting the skeleton.

\subsubsection{MIL53 (Al) and Cu-BTC Adsorbents}

Received II November 2020; Received in revised form 25 November 2020; Accepted 25 November 2020;

Available online 17 December 2020

doi: 10.46291/ICDNTECHvol4iss33pp30-42 
Metal organic frameworks namely MIL53 (Al) and Cu-BTC demonstrate higher surface area (1278 and $1473 \mathrm{~m}^{2} / \mathrm{g}$, respectively) and micropore volume $\left(0.4\right.$ and $0.43 \mathrm{~cm}^{3 / g}$, respectively) than zeolites (about $1000 \mathrm{~m}^{2} / \mathrm{g}$ and $0.3 \mathrm{~cm}^{3 /} \mathrm{g}$, respectively). MIL53 (Al) adsorbent has smaller crystals than Cu-BTC adsorbent (Figure 3 and 4, respectively).

\section{2. $\mathrm{CO}_{2}$ Adsorption Studies}

Figures $5 \mathrm{a}$ and $5 \mathrm{~b}$ show the adsorption isotherm of $\mathrm{CO}_{2}$ adsorption on the zeolites and MOFs obtained at $278 \mathrm{~K}$ and $298 \mathrm{~K}$, respectively. As shown in the figures, similar and highly favorable adsorption isotherms which are of type 1, according to IUPAC classification, were observed for zeolite adsorbents while linear isotherms were noticed for the MOF adsorbents. Zeolites have similar and highly favorable adsorption isotherms which are of type 1 , according to IUPAC classification, whereas MOF adsorbents have linear isotherms. The temperature increased the amount adsorbed by the adsorbents since adsorption is an exothermic process. NaX zeolite has the higher $\mathrm{CO}_{2}$ adsorption than $\mathrm{K}$ exchanged $\mathrm{NaX}$ zeolite, due to its higher electropositivity and ionic radius of $\mathrm{Na}^{+}$ion than those of $\mathrm{K}^{+}$ion. $\mathrm{NaX}$ is the most basic surfaces among the zeolites. The $\mathrm{CO}_{2}$ adsorption data were fitted to Langmuir, Freundlich, Toth and Sips models (as representatively shown in Figure 6). Among them Toth model equation,

$$
q=\frac{q_{m} b P}{\left(1+(b P)^{t}\right)^{1 / t}}
$$

was the best method to describe the experimental data as discussed by Yerkesikli. ${ }^{20}$ Where $\mathrm{q}$ and $\mathrm{q}_{\mathrm{m}}$ represent the amount adsorbed and monolayer adsorption capacity (mmol/g adsorbent), $\mathrm{P}(\mathrm{kPa})$ is the gas pressure inside the pores at equilibrium. Parameter " $t$ " and " $b$ " $\left(\mathrm{kPa}^{-1}\right)$ of the model equation characterize the heterogeneity of the $\mathrm{CO}_{2}$-adsorbent system and the affinity of adsorbent to $\mathrm{CO}_{2}$, respectively. Table 2 shows the Toth's parameter and the errors defined. It was concluded that the sum of square error (SSE), in harmony with regression coefficient, is less sensitive than the standard error (SE). As stated by Do ${ }^{21}$ the parameter "t" deviates from unity, suggesting that the system was "apparently" more heterogeneous. Among the zeolites, $\mathrm{CO}_{2}-\mathrm{NaX}$ pair is the most heterogeneous; the heterogeneity of the $\mathrm{CO}_{2}-\mathrm{KNaXs}$ systems decreases with increasing exchange percentage. Our results agree with the results obtained by Walton et al. ${ }^{15}$ Among the adsorbents, CuBTC has the lowest heterogeneity. Parameter "b", the affinity constant, decreases as the temperature increases; zeolite adsorbents have higher $b$ values than MOF adsorbents showing that $\mathrm{CO}_{2}$ molecule is preferentially attracted onto the zeolite surfaces. Among the zeolite adsorbents $\mathrm{NaX}$ zeolite was the most attractive adsorbent for $\mathrm{CO}_{2}$.

\subsubsection{Isosteric heat of adsorption}

In addition to the surface area, pore volume, and adsorption capacity, the isosteric heat of adsorption is an important parameter to evaluate the adsorption performance of adsorbents. Therefore the Van't Hoff equation

Received II November 2020; Received in revised farm 25 November 2020; Accepted 25 November 202D;

Available online 17 December 2020

dai: 10.4629I//CONTECHvol4iss3pp30-42 
$-\frac{q_{s t}}{R T^{2}}=\left[\frac{\partial \ln P}{\partial T}\right]_{V}$

and Toth equation were used to obtain isosteric heat of adsorption as a function of adsorbate loading. ${ }^{21}$

$q_{s t}=\left.q_{s t}\right|_{q \rightarrow 0}-t(\alpha R T)\left[\ln \left(\frac{q}{\left.q_{m}{ }^{t}-q t\right)^{(1 / t)}}\right)\right]-\frac{\ln \left(q_{m}\right)}{1-\left(q / q_{m}\right) t}$

Where, $\left.q_{s t}\right|_{q \rightarrow 0}, \mathrm{R}, \mathrm{T}$ and $\mathrm{P}$ are the isosteric heat of adsorption at zero loading, the gas constant (8.314( $\mathrm{LkPa} / \mathrm{mol} \mathrm{K}))$, temperature(K), and pressure(kPa), respectively. Figure 7 shows the variation of the isosteric heat of adsorption with the amount adsorbed, q. As expected for heterogeneous systems the $\mathrm{CO}_{2}$ adsorbent interaction decreases with increasing amount adsorbed, since the stronger binding sites would be occupied first. However, this change does not point out the source of heterogeneity, whether it is the solid structural property, energetic property of the solid or the sorbate. In other words, heterogeneity is not a solid characteristic alone but rather it is a characteristics of the specific solid and adsorbate pair. ${ }^{16,21}$

The isosteric heat of adsorption at zero loading $\left(\left.q_{s t}\right|_{q \rightarrow 0}\right)$ of $\mathrm{NaX}(55 \mathrm{~kJ} / \mathrm{mol})$ is higher than $\mathrm{KNaX}$ zeolites. This is attributed to the strongest interaction between the large quadrupole moment of $\mathrm{CO}_{2}$ and the cations. The isosteric heat of adsorption at zero loading for Cu-BTC and MIL53 (Al) (40 kJ/mol and $38 \mathrm{~kJ} / \mathrm{mol}$, respectively) has lower value than zeolites. This low isosteric heat indicates that $\mathrm{CO}_{2}$ molecules weakly interact with MOFs. The isosteric heat of adsorption of MOFs obtained in this study is comparable with the measured value $(34 \mathrm{~kJ} /$ mol) of MOF-5 in the literature. ${ }^{2}$

\section{EXPERIMENTAL}

\subsubsection{Preparation of the adsorbents}

Binderless NaX zeolite (Cas\# 63231-69-6) from Aldrich with unit cell formula of $\mathrm{Na}{ }_{86}\left(\mathrm{Al}_{86} \mathrm{Si}_{106} \mathrm{O}_{384}\right) 264 \mathrm{H}_{2} \mathrm{O}$, and $\mathrm{Si} / \mathrm{Al}: 1.23$ was used. Commercial metal organic frameworks MIL53 (Al) and Cu-BTC (Basolite A100 and Basolite C300, respectively) were supplied from Aldrich. In preparation of $\mathrm{KNaX}$, ultrasound is employed as an alternative method to traditional ion exchange method as given detailed in the previous study. ${ }^{18} 2 \mathrm{~g}$ of zeolite were mixed with $20 \mathrm{~mL}$ of $1 \mathrm{M} \mathrm{KCl}$ solution for $2 \mathrm{~h}$ at $50^{\circ} \mathrm{C}$ or $70{ }^{\circ} \mathrm{C}$ with water bath shaker (GFL 1092) at 130 rpm (in traditional method) or ultrasonic processor (Sonics-Vibracell-VC 505) at $16 \mathrm{kHz}$ frequency (in ultrasonic method). The mixtures were centrifuged and then zeolite phases were washed with water until $\mathrm{Cl}^{-}$free solutions were obtained. The solutions were analyzed by using 
inductively Coupled Plasma Atomic Emission Spectroscopy (ICP-AES 96, Varian) to calculate Na exchange percentage, $\eta_{N a} ; \quad \eta_{N a}=\left(\frac{q_{o}-q_{N a}}{q_{o}}\right) \times 100$

where $q_{o}$ and $q_{N a}\left(\mathrm{mg} \mathrm{g}^{-1}\right)$ are the initial and equilibrium (after $2 \mathrm{~h}$ ) amount of $\mathrm{Na}^{+}$ions into zeolites, respectively. In Na exchanged zeolite codes, $\mathrm{U}$ and $\mathrm{S}$ represents the ion exchange methods: ultrasound and traditional respectively; 50 and 70 are temperatures in ${ }^{\circ} \mathrm{C}$ unit; the number in the parenthesis is Na exchange percent (\%). All chemicals are analytical grade and were purchased from Aldrich.

\subsubsection{Characterization of Adsorbents}

Mineralogy and crystallinity of the adsorbents were determined by X-ray diffraction (Philips $\mathrm{X}$-Pert Pro Diffractometer) using CuK $\mu$ radiation at $45 \mathrm{kV}$ and $40 \mathrm{~mA}$ in the $2 \mathrm{q}$ range of 5-70 ${ }^{\circ}$ with $0.2^{\circ}$ step size. The micrographs of the adsorbents were taken by using scanning electron microscopy (SEM, Philips XL 30S). Chemical composition of the zeolite adsorbents was determined by Inductively Coupled Plasma Atomic Emission Spectroscopy (ICP-AES, 96, Varian). Textural properties of adsorbents were determined by using a volumetric $\mathrm{N}_{2}$ adsorption instrument (Micromeritics, ASAP 2010M) at 77K. Prior to adsorption, the samples were degassed at $350{ }^{\circ} \mathrm{C}$ for $24 \mathrm{~h}$ under vacuum better than $10^{-5} \mathrm{mbar}$.

\subsection{3. $\mathrm{CO}_{2}$ Adsorption}

Adsorption of $\mathrm{CO}_{2}$ on the adsorbents were measured in a volumetric adsorption instrument (Micromeritics ASAP 2010M) at 278 and $298 \mathrm{~K}$. Toth adsorption models were used to correlate the $\mathrm{CO}_{2}$ adsorption. The fitting of the isotherm data to the model equations was carried out by using Sigma Plot 6.01 statistical software program.

\section{CONCLUSION}

$\mathrm{K}^{+}$ion exchange on NaX zeolite was conducted at $50{ }^{\circ} \mathrm{C}$ and at $70{ }^{\circ} \mathrm{C}$ by means of traditional and ultrasound methods. The ultrasonic method was found to be more effective on the exchange due to the cavitational effect of ultrasound field. Additional to KNaX zeolites, MIL53 (Al) and $\mathrm{Cu}-\mathrm{BTC}$ adsorbents were evaluated as a potential adsorbent for $\mathrm{CO}_{2}$ adsorption. $\mathrm{CO}_{2}$ adsorption data fitting to the theoretical models lead us to the conclusion that $\mathrm{CO}_{2}$-adsorbents are heterogeneous systems; isosteric heat of $\mathrm{CO}_{2}$ adsorption on zeolite and MOF adsorbents decreases with loading. Compared with the zeolites, the MOF adsorbents used in this study have higher Langmuir specific surface area and lower isosteric heat of adsorption at zero loading. This is essential for adsorption application because of the large energy requirement associated with the regeneration (i.e. desorption) of the adsorbents. 


\section{ACKNOWLEDGMENT}

This study was financially supported by TUBITAK (project number: 112M294) and Izmir Institute of Technology (project number: 2011IYTE09).

\section{REFERENCES}

1. Yaghi, O. M.; O'Keeffe, M.; Ockwig, N. W.; Chae, H. K.; Eddaoudi, M.; Kim, J. Nature, 2003, 423, 705-714.

2. Zhao, Z. X.; Li, Z.; Lin, Y. S. Ind Eng Chem Res, 2009, 48, 10015-10020.

3. Xue, M.; Ma, S.; Jin, Z.; Schaffino, R. M.; Zhu, G. S.; Lobkovsky, E. B.; Qiu, S. L.; Chen, B. Inorg Chem, 2008, 47, 6825-6828.

4. Wang, B.; Cote, A. P.; Furukawa, H.; O'Keeffe, M.; Yaghi, O. M. Nature, 2008,453, 207-211.

5. Ramos, M. J.; Jimenez, V.; Funez, A.; Romero, A.; Sanchez, P. Valverde, J. L. Catal Lett, 2008, 125, 220-228.

6. Millward, A. R.; Yaghi, O. M. J Am Chem Soc, 2005, 127, 17998-17999.

7. Martin, C.; Tosi-Pellenq, N.; Patarin, J.; Coulomb, J. P. Langmuir, 1998, 14, 17751778.

8. Llewellyn, P. L.; Bourrelly, S.; Serre, C.; Filinchuk, Y.; Ferey G. Angew Chem. Int Edition, 2006, 45, 7751-7754.

9. Huang, H. Y.; Yang, R. T.; Chinn, D.; Munson, C. L. Ind Eng Chem Res, 2003, 42, 2427-2433.

10. Hayashi, H.; Cote, A. P.; Furukawa, H.; O'Keeffe, M.; Yaghi, O. M. Natural Material, 2007, 6, 501-506.

11. Harlick, P. J. E.; Tezel, F. H., Micropor Mesopor Mat, 2004, 76, 71-79.

12. Dunne, J. A.; Rao, M.; Sircar, S.; Gorte, R. J. ; Myers, A. L. Langmuir, 1996, 12, 58965904.

13. Bourrelly, S.; Llewellyn, P. L.; Serre, C.; Millange, F.; Loiseau, T.; Ferey, G. J Am Chem Soc, 2005, 39, 13519-13521.

14. Ferey, G.; Latroche, M.; Serre, C.; Millange, F.; Loiseau, T. Chemical Communications, 2003, 24, 2976-2977.

15. Walton, K. S.; Abney, M. B.; LeVan, M. D. Micropor Mesopor Mat, 2006, 91, 78-84. 
16. Yang, C.; Xu, Q. H. Chem J Chinese U, 1996, 17, 1336-1340.

17. Barthomeuf, D. Micropor Mesopor Mat, 2003, 66, 1-14.

18. Erten-Kaya, Y. ; Cakicioglu-Ozkan F. Ultrason Sonochem, 2012, 19, 701-706.

19. Jasra, R.V. Tyagi, B. Badheka, Y.M.; Choudary, V.N. Bhat, T.S.G. Ind Eng Chem Res, 2003, 42, 3263-3272.

20. Yerkesikli, A.G. PhD, the Graduate School of Engineering \& Science, İzmir Institue of Technology, TR, 2013.

21. Do, D.D. Adsorption Analysis: Equilibria and Kinetics, Imperial College Press: London, 1998. 


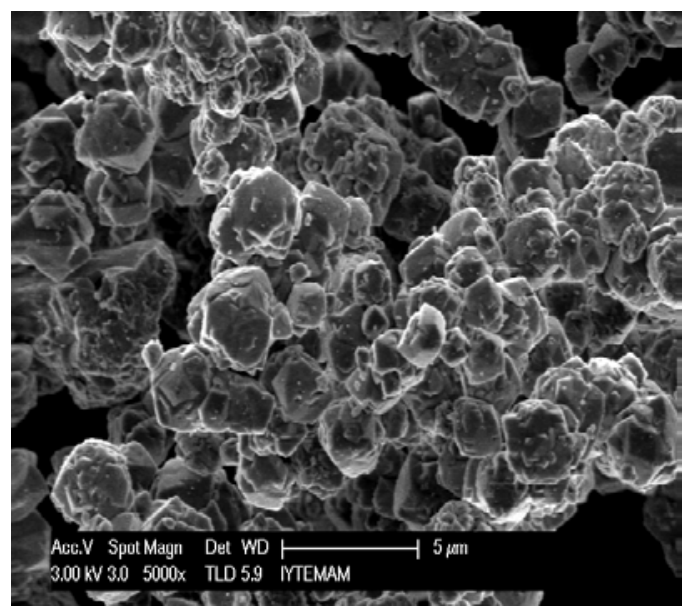

(a)

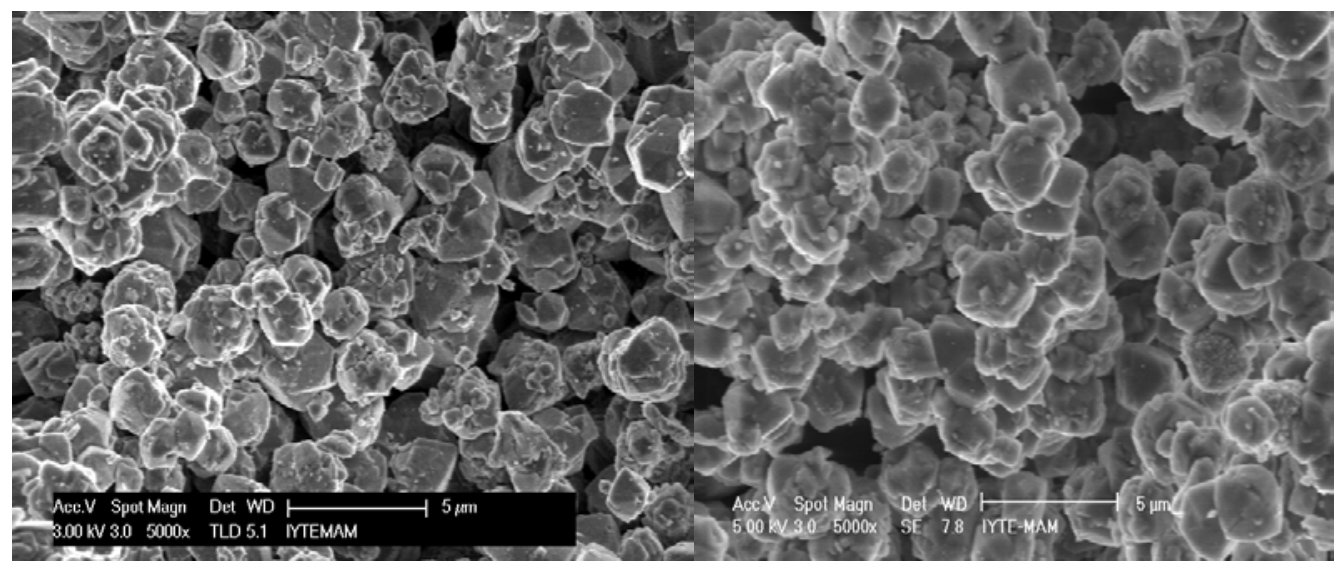

(b)

(c)

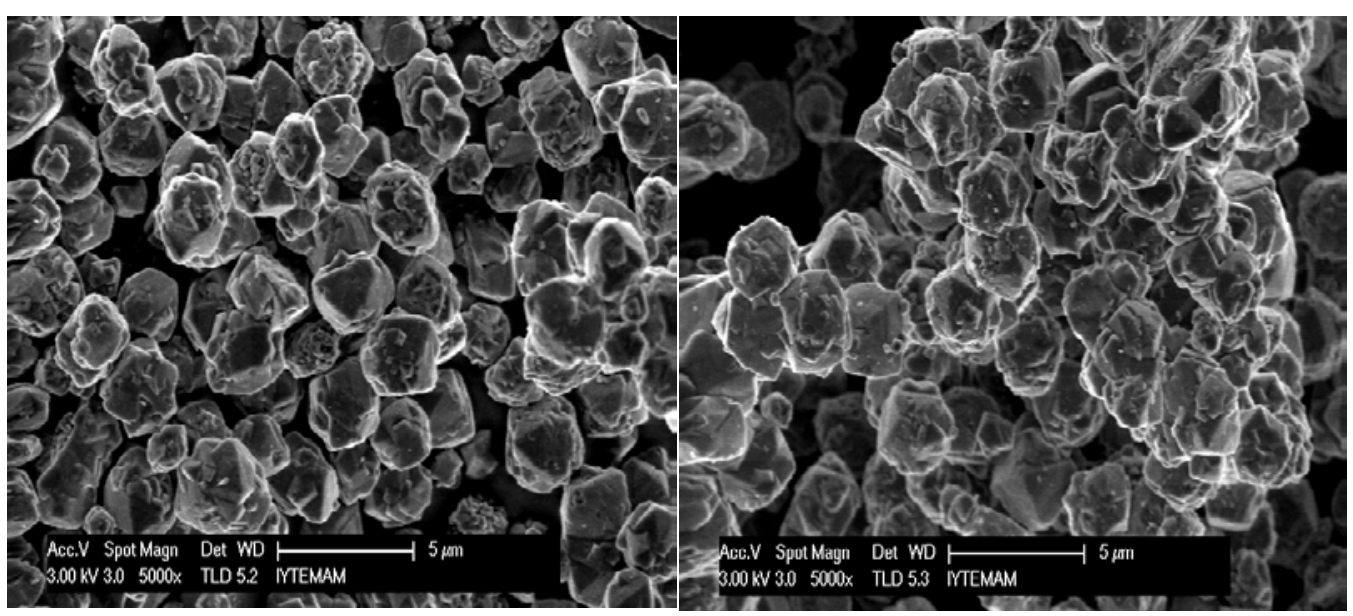

(d)

(e)

Figure 1: Scanning Electron Micrographs of the zeolites surfaces

Received II November 2020; Received in revised form 25 November 2020; Accepted 25 November 2020; Available unline 17 December 2020 doi: 10.46291//CDNTECHvol4iss3pp30-42 


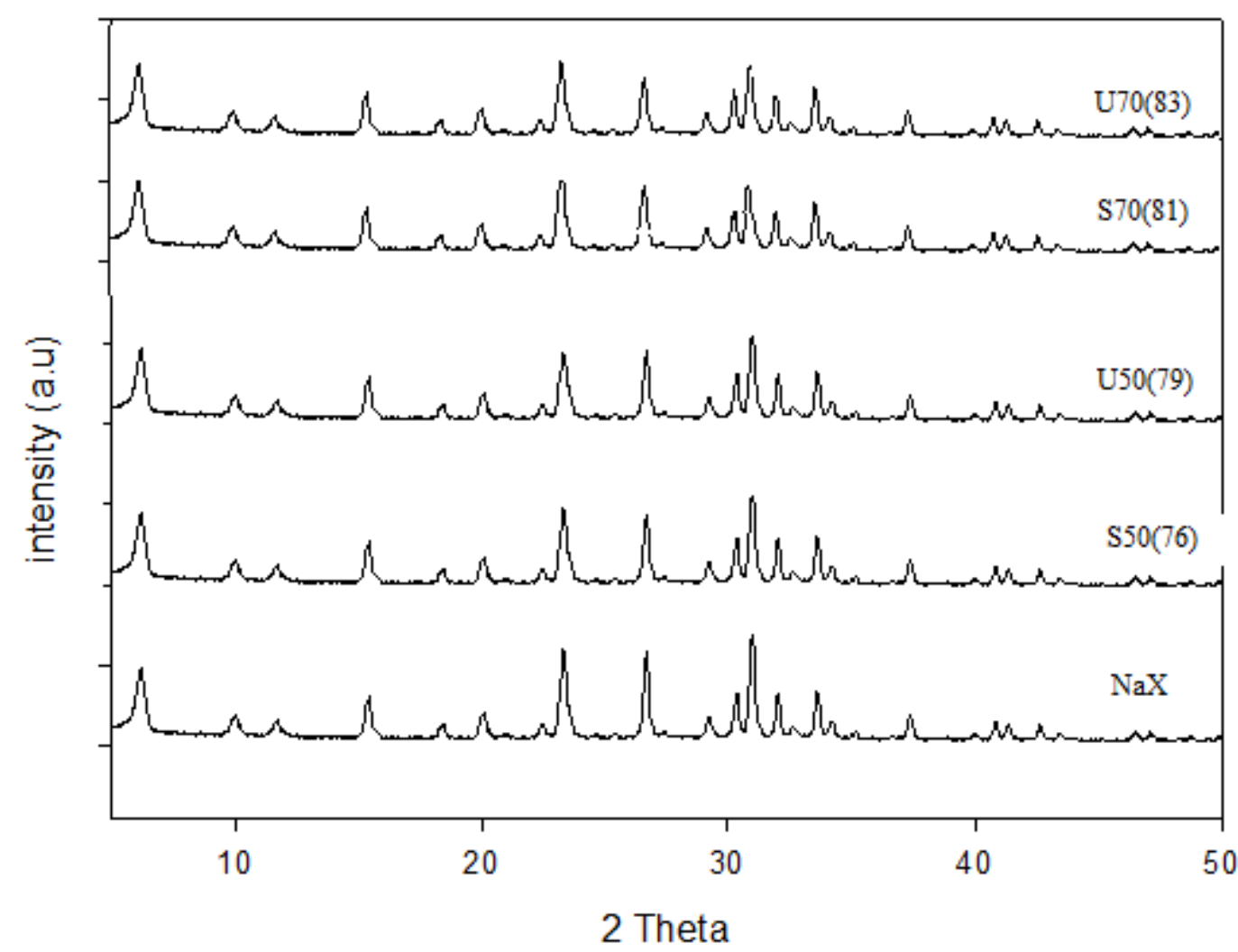

Figure 2: X-ray diffractogram of the zeolite adsorbents

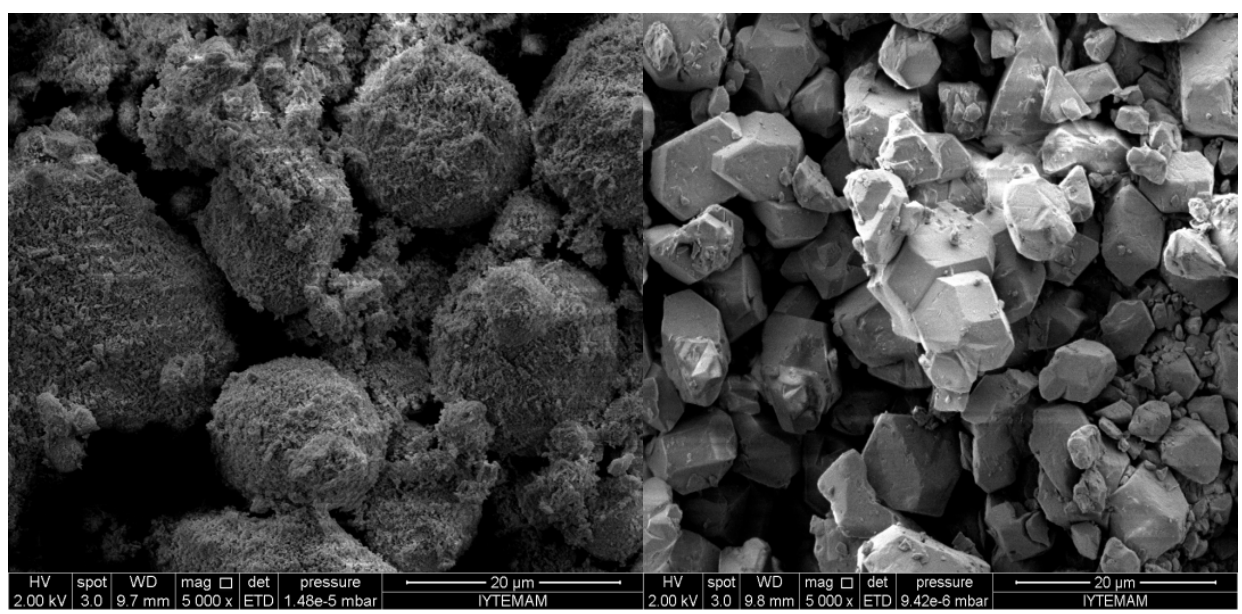

(a)

(b)

Figure 3: Scanning Electron Micrographs of the (a) MIL53(Al) and (b) CuBTC surfaces 


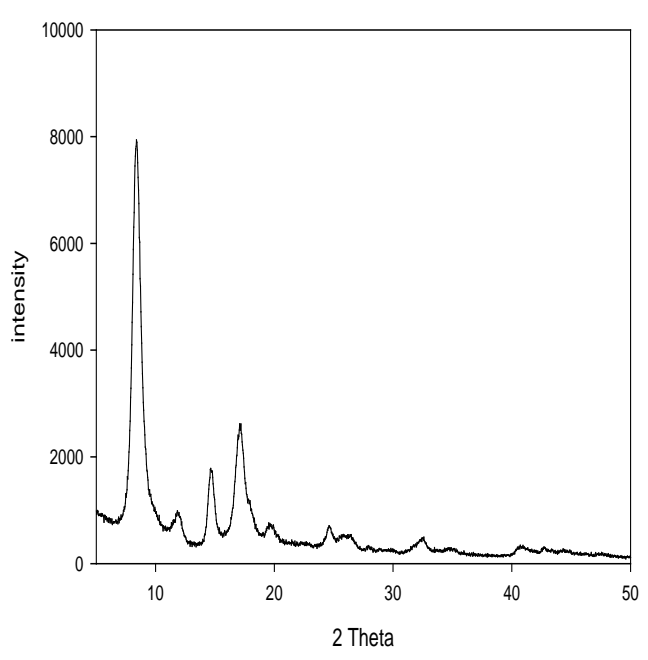

(a)

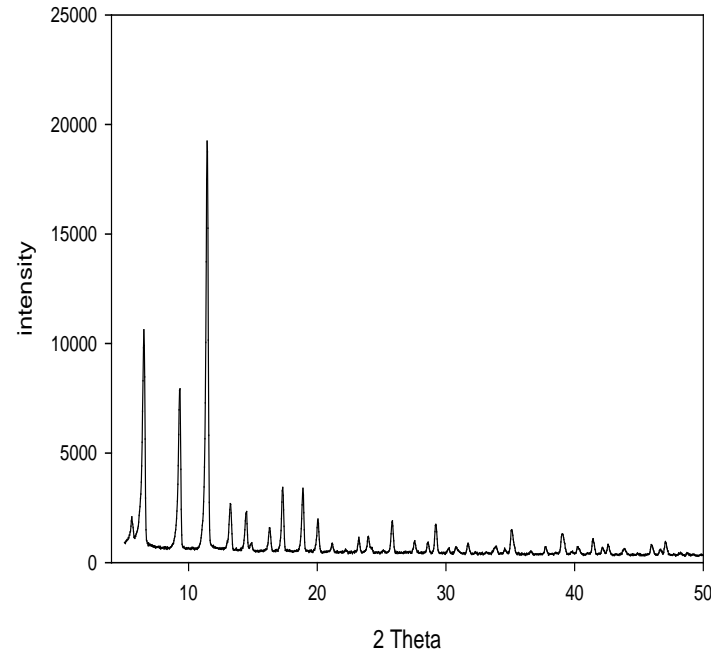

(b)

Figure 4: XRD Pattern of the (a) MIL53(Al) and (b) CuBTC adsorbents

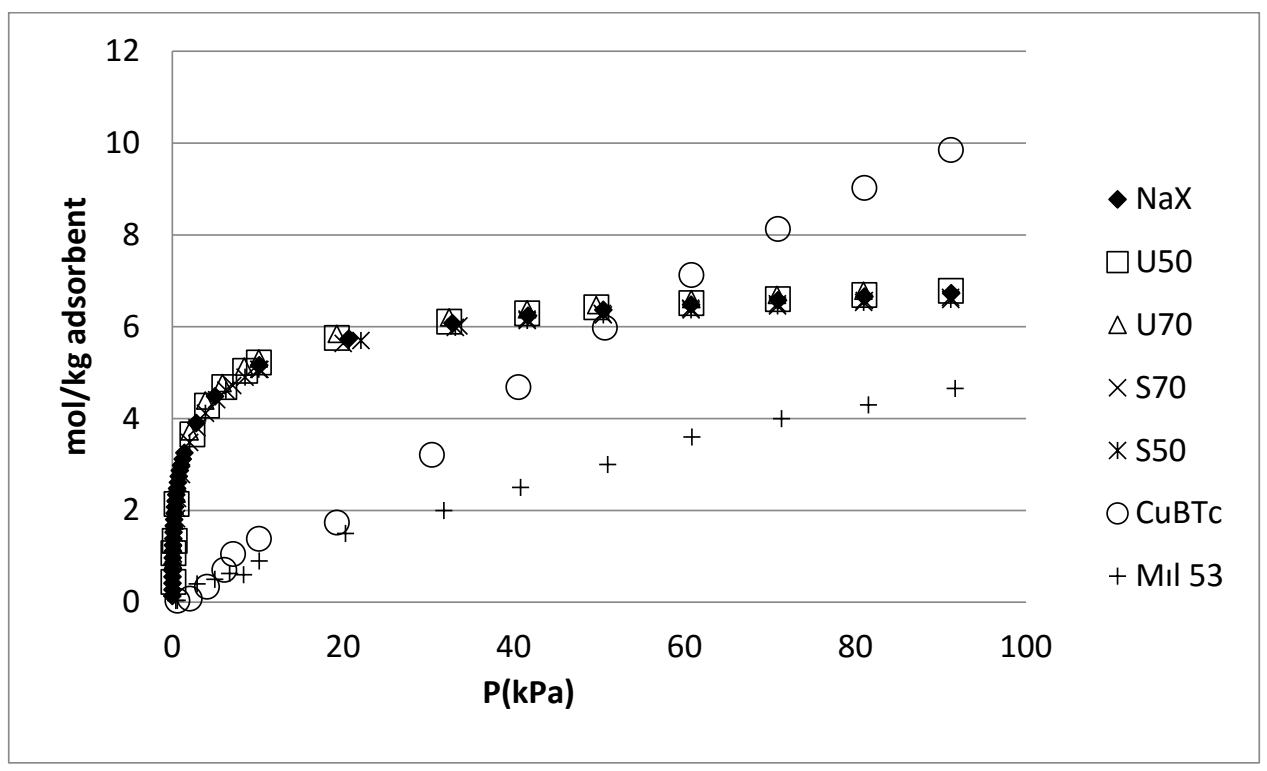

(a)

Received II November 2020; Received in revised form 25 November 202D; Accepted 25 November 202D; 


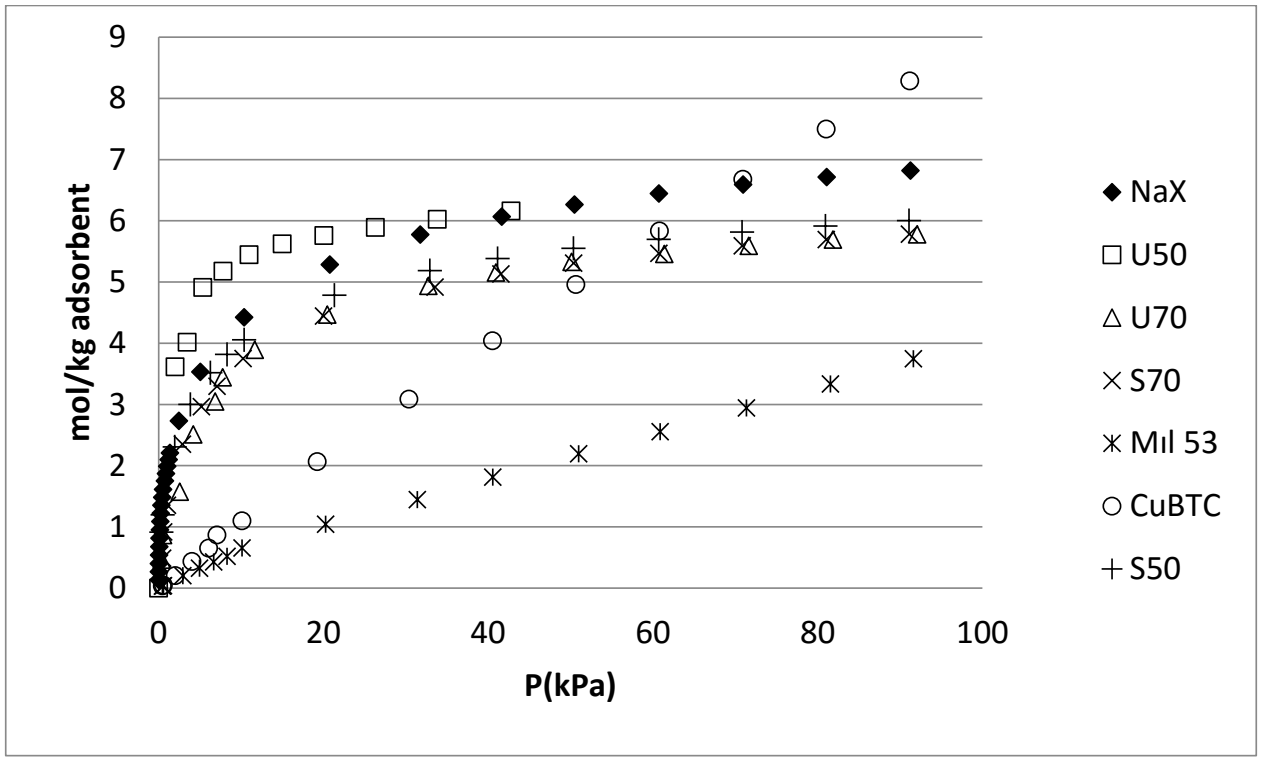

(b)

Figure 5: $\mathrm{CO}_{2}$ adsorption isotherm of the zeolites and MOFs at 278K (a) and 298K (b)

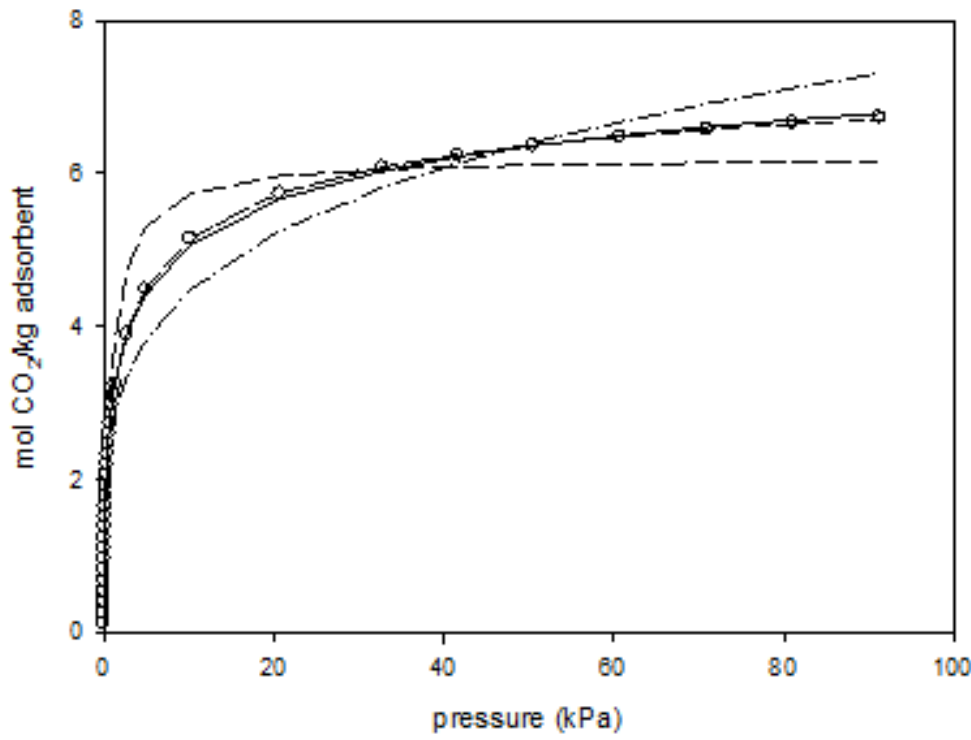

Figure 6: Adsorption isotherms of $\mathrm{CO}_{2}$ at $278 \mathrm{~K}$ of $\mathrm{NaX}$ zeolite (points: experimental, model: curve fittings Langmiur: $-\ldots$ - Freundlich:-_-_- Sips: $-\_-$- Toth: 


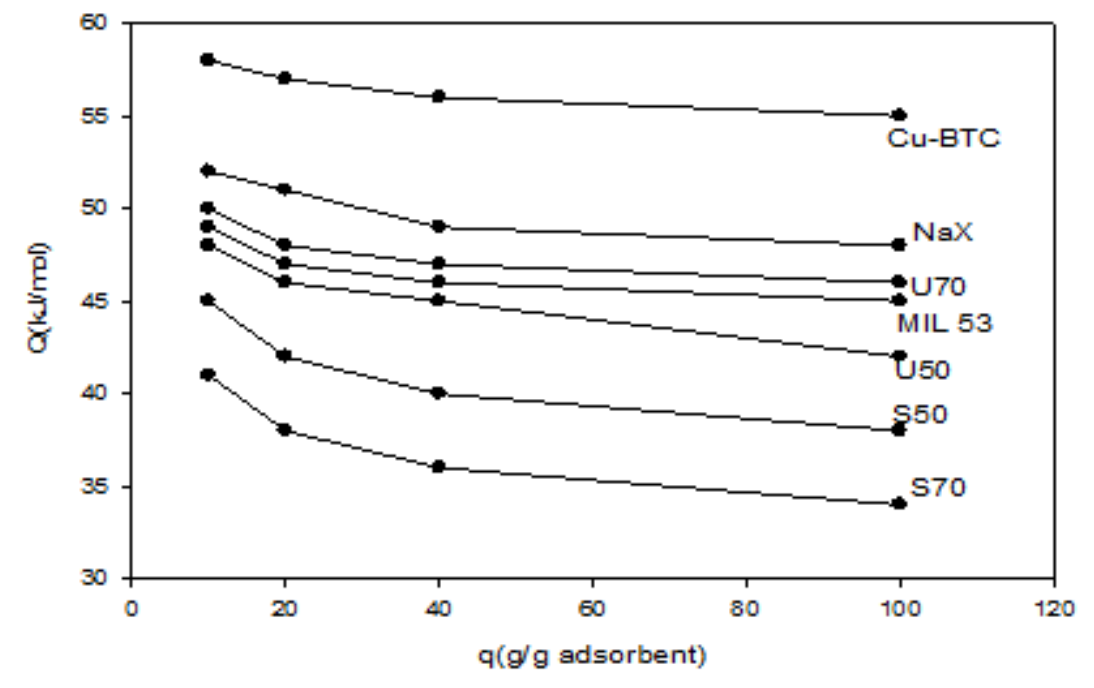

Figure 7: Comparison between isosteric heats calculated from Toth model equations for the adsorbents.

\begin{tabular}{|c|c|c|c|}
\hline Adsorbent codes* & $A_{\mathrm{L}} / \mathrm{m}^{2} \mathrm{~g}^{-1}$ & $V_{\mathrm{mic}} / \mathrm{cm}^{3} \mathrm{~g}^{-1}$ & $\mathrm{~d}_{\mathrm{m}} /(\AA)$ \\
\hline $\mathrm{NaX}$ & 1058 & 0.37 & 7.47 \\
\hline $\mathrm{U} 50(79)$ & 899 & 0.31 & 6.55 \\
\hline U70 (83) & 1036 & 0.34 & 5.67 \\
\hline S50 (76) & 902 & 0.31 & 7.15 \\
\hline S70 (81) & 857 & 0.33 & 7.10 \\
\hline MIL 53 & 1278 & 0.4 & 8.55 \\
\hline CU-BTC & 1473 & 0.43 & \\
\hline
\end{tabular}

*: Numbers in the parentheses are Na exchange amount\%

$A_{\mathrm{L}}$ : Surface area from Langmuir method; $V_{\text {mic }}$ : micropore volume, $\mathrm{d}_{\mathrm{m}}$ : median pore diameter from Howard-Kawazoe Method

Table 1: Textural properties of adsorbents 
ICONTECH INTERNATIONAL JOURNAL OF SURVEYS, ENGINEERING, TECHNOLOGY ISSN 2717-7270

Journal homepage: http://icontechjournal.com/index.php/iij

\begin{tabular}{|c|c|c|c|c|c|c|c|c|c|c|c|c|c|}
\hline \multirow{2}{*}{$\begin{array}{c}\text { Para } \\
\text { meter }\end{array}$} & \multicolumn{2}{|c|}{ NaX } & \multicolumn{2}{|c|}{ U70(86) } & \multicolumn{2}{|c|}{ S50(76) } & \multicolumn{2}{|c|}{ U50(79) } & \multicolumn{2}{|c|}{ S70(81) } & \multicolumn{2}{|c|}{ MIL 53 (Al) } & \multirow{2}{*}{$\begin{array}{c}\text { Cu- } \\
\text { BTC } \\
278 K\end{array}$} \\
\hline & $278 K$ & $298 K$ & $278 K$ & $298 K$ & $278 K$ & $298 K$ & $278 K$ & $298 K$ & $278 K$ & $298 K$ & $278 K$ & $298 K$ & \\
\hline$q_{m}$ & 7.10 & 6.89 & 6.90 & 6.69 & 7.30 & 7.10 & 7.70 & 6.54 & 7.10 & 6.50 & 1.70 & 1.40 & 5.60 \\
\hline $\begin{array}{c}b\left(k P a^{-}\right. \\
1)\end{array}$ & 0.28 & 0.2 & 0.17 & 0.166 & 0.22 & 0.21 & 0.15 & 0.139 & 0.19 & 0.171 & 0.0009 & 0.0009 & 0.004 \\
\hline$t$ & 0.24 & 0.29 & 0.54 & 0.61 & 0.35 & 0.4 & 0.67 & 0.69 & 0.43 & 0.5 & 0.71 & 0.82 & 0.24 \\
\hline$R^{2}$ & 0.9973 & 0.9994 & 0.9994 & 0.9986 & 0.9993 & 0.9990 & 0.9999 & 0.995 & 0.9964 & 0.9994 & 0.99999 & 0.98 & 0.9998 \\
\hline$S E$ & 0.09 & 0.04 & 0.04 & 0.07 & 0.05 & 0.07 & 0.02 & 0.13 & 0.13 & 0.04 & 0.0036 & 0.11 & 0.02 \\
\hline SSE & 0.13 & 0.02 & 0.02 & 0.06 & 0.10 & 0.14 & 0.007 & 0.21 & 0.026 & 0.01 & 0.001 & 0.001 & 0.007 \\
\hline
\end{tabular}

$$
S S E=\sum_{i=1}^{m}\left(Q_{i}-q_{i}\right)^{2}
$$

Sum of square error:

$\mathrm{q}_{\mathrm{i}}$ : observation from the batch experiment $\mathrm{i}, \mathrm{Q}_{\mathrm{i}}$ is the estimate from the isotherm for corresponding $\mathrm{q}_{\mathrm{i}}$

Standard error: $\quad S E=\left[\frac{1}{m-p} \sum_{i=1}^{m}\left(Q_{i}-q_{i}\right)^{2}\right]^{0.5}$

m: number of observations in the experimental isotherm, p: number of parameters in the regression model

$\mathrm{q}_{\mathrm{m}}=$ the amount adsorbed (mmole $\mathrm{CO}_{2} / \mathrm{g}$ zeolite) at monolayer coverage

Table 2: Isotherm Model fitting for $\mathrm{CO}_{2}$ adsorption data

Received 26 Lctaber 2020; Received in revised form I December 2020; Accepted 5 December 2020;

Available online 17 December 2020

doi: 10.46291//CONTECHvol4iss3pp30-42 